\title{
SISTEM INFORMASI PENGOLAHAN DATA BALITA BERBASIS WEBSITE PADA KANTOR UPT-KB KEC. TERNATE SELATAN
}

\section{TODDLER DATA MANAGEMENT INFORMATION SYSTEM WITH A WEBSITE IN THE OFFICE OF UPT-KB DISTRICT TERNATE SOUTH}

\author{
Muhdar Abdurahman ${ }^{1}$, Mudar Safi $^{2}$, Muksin Hi Abdullah ${ }^{3}$ \\ ${ }^{1}$ Prodi Manajemen Informatika, ${ }^{2,3}$ Prodi Teknik Komputer \\ Akademi Ilmu Komputer (AIKOM) Ternate \\ muhdar.abdrahman@gmail.com
}

\begin{abstract}
Abstrak
Kantor UPT-KB Kec. Ternate Selatan salah satu instansi dikota ternate yang bergerak di bidang kesehatan yang salah satu tugasnya adalah mengolah data balita, dimana pengolahan data tersebut sudah menggunakan sistem secara komputerisasi, akan tetapi masih dilakukan menggunakan aplikasi word dan excel dalam pembuatan laporan data balita harus sering berpindah-pindah dari salah satu aplikasi yaitu word ke excel dan begitupun sebaliknya, hal ini dikarenakan ada proses hitungan data balita yang dilakukan pada aplikasi excel dan di rekap ke aplikasi word sehingga harus berpindah aplikasi sehingga dianggap belum efektif dan efisien, Tujuan Penilitian ini untuk merancang Sistem Informasi Pengolahan Data Balita berbasis web pada Kantor UPT-KB Ternate Selatan, Metode Pengumpulan data yang digunakan adalah observasi dan interview, Model dan tools yang digunakan dalam rancangan sistem adalah DFD, ERD, serta bahasa pemrograman HTML, CSS dan PHP, sistem ini dapat memberikan kemudahan dalam proses pengolahan dan penyajian informasi data balita pada Kantor UPT-KB Kec. Ternate Selatan
\end{abstract}

\section{Kata kunci: Sistem Informasi, Data Balita, Website}

\begin{abstract}
Office of UPT-KB Kec. South Ternate, one of the agencies in the city of Ternate which are engaged in health, one of its tasks is to process data on toddlers, where data processing is already using a computerized system but still done using word and excel applications in making data reports toddlers must often move from one application that is word to excel and vice versa, this is because there is a toddler data count process that is done on the excel application and recap to the word application so it must switch applications so that it is considered not effective and efficient, The purpose of this study was to design a web-based Toddler Data Processing Information System at the Office of UPT-KB South Ternate, Data collection method used is observation and interview, Models and tools used in system design are DFD, ERD, as well as HTML, CSS and PHP programming languages, this system can provide convenience in the process of processing and presenting information on toddler data at the Office of UPT-KB Kec. South Ternate
\end{abstract}

Keywords: Information System, Data Toddlers, Website 


\section{PENDAHULUAN}

Perkembangan Teknologi Informasi sangat cepat. Komputer sebagai salah satu sarana penunjang yang membantu dalam dunia pekerjaan, adalah menyediakan suatu sistem yang dapat menghasilkan informasi secara cepat dan efisien, sistem informasi merupakan output yang baik pada sebuah sistem.

Menurut Mulyadi (2016:4), "Sistem adalah suatu jaringan prosedur yang dibuat menurut pola yang terpadu untuk melaksanakan kegiatan pokok perusahaan, Sedangkan sistem informasi menurut (Sutabri, 2004), adalah: "suatu sistem didalam suatu organisasi yang mempertemukan kebtuhan pengolahan transaksi harian yang mendukung fungsi operasi organisasi yang bersifat manajeerial dengan kegiatan strategi dari suatu organisasi untuk dapat menyediakan kepada pihak luar tertentu dengan laporanlaporan yang diperlukan."

Kantor UPT-KB Kec. Ternate Selatan salah satu instansi dikota ternate yang bergerak di bidang kesehatan yang salah satu tugasnya adalah mengolah data balita, dimana pengolahan data tersebut sudah menggunakan sistem secara komputerisasi, akan tetapi masih dilakukan menggunakan aplikasi word dan excel dalam pembuatan laporan data balita harus sering berpindah-pindah dari salah satu aplikasi yaitu word ke excel dan begitupun sebaliknya, hal ini dikarenakan ada proses hitungan data balita yang dilakukan pada aplikasi excel dan di rekap ke aplikasi word sehingga harus berpindah aplikasi oleh karena itu system tersebut dianggap blm efektif dan efisien.

Berdasarkan gambaran masalah sebelumnya maka dianggap perlu untuk membuat suatu sistem informasi yang dapat mengolah data balita secara terkomputerisasi pada satu system saja tanpa harus berpindah-pindah system yang didalamnya dapat menghitung dan merekap laporan data balita secara keseluruhan.

\section{Rumusan Masalah}

Berdasarkan latar belakang yang telah dikemukakan, maka dapat diuraikan pokok permasalahan, diantaranya sebagai berikut : Bagaimana merancang Sistem Informasi Pengolahan Data Balita pada Kantor UPTKB Kec. Ternate Selatan Berbasis Website, Sistem yang dirancang hanya untuk mengelola dan menghasilkan informasi data balita, diharapkan dapat memberikan kemudahan dalam proses pengolahan dan penyajian informasi data balita pada Kantor UPT-KB Kec. Ternate Selatan

\section{LANDASAN TEORI}

\section{Pengertian dan Tujuan Sistem}

Menurut Azhar Susanto (2013:22) Sistem adalah kumpulan/group dari sub sistem/bagian/komponen apapun baik phisik ataupun non phisik yang saling berhubungan satu sama lain dan bekerja sama secara harmonis untuk mencapai satu tujuan tertentu

Menurut Tata Sutabri (2012:6) pada dasarnya sistem adalah sekelompok unsur yang erat hubungannya satu dengan yang lain, yang berfungsi bersama-sama untuk mencapai tujuan tertentu.

Adapun tujuan sistem menurut Azhar Susanto (2013:23) sistem merupakan target atau sasaran akhir yang ingin dicapai oleh suatu sistem. Agar supaya target tersebut bisa tercapai, maka target atau sasaran tersebut harus diketahui terlebih dahulu ciri-ciri atau kriterianya. Upaya mencapai suatu sasaran tanpa mengetahui ciri-ciri atau kriteria dari 
sasaran tersebut kemungkinan besar sasaran tersebut tidak akan pernah tercapai. Ciri-ciri atau kriteria dapat juga digunakan sebagai tolak ukur dalam menilai suatu keberhasilan suatu sistem dan menjadi dasar dilakukannya suatu pengendalian “.

\section{Pengertian Informasi}

Menurut Agus Mulyanto (2009:12) Informasi adalah data yang diolah menjadi bentuk yang lebih berguna dan lebih berarti bagi yang menerimanya, sedangkan data merupakan sumber informasi yang menggambarkan suatu kejadian yang nyata

Tata Sutabri (2012:22) pada buku Analisis Sistem Informasi, Informasi adalah data yang telah diklasifikasikan atau diolah atau diinterpretasikan untuk digunakan dalam proses pengambilan keputusan

\section{Pengertian Sistem Informasi}

Menurut O'Brian dikutip oleh Yakub (2012:17) Sistem informasi (information system) merupakan kombinasi teratur dari orang-orang, perangkat keras, perangkat lunak, jaringan komunikasi, dan sumber daya data yang mengumpulkan, mengubah, menyebarkan informasi dalam sebuah organisasi.

\section{Pengolahan Data}

Hutahaean (2014:8), menjelaskan tentang pengertian pengolahan data menurut ahli sebagai berikut: George R. Terry menyatakan, "Pengolahan data adalah serangkaian operasi atas informasi yang direncanakan guna mencapai tujuan atau hasil yang diinginkan".

Sutarman (2012:4), "Pengolahan Data adalah proses perhitungan/transformasi data input menjadi informasi yang mudah dimengerti ataupun sesuai dengan yang diinginkan"

\section{Pengertian Flowchart}

EWolf Community (2011:16), "Flowchart adalah simbol-simbol pekerjaan yang menunjukkan bagan aliran proses yang saling terhubung, setiap simbol flowchart melambangkan pekerjaan dan instruksinya."

\section{Pengertian ERD}

Sukamto dan Salahudin (2014:50), "Entity Relationship Diagram (ERD) dikembangkan berdasarkan teori himpunan dalam bidang matematika. Entity Relationship Diagram (ERD) digunakan untuk pemodelan basis data relational. Sehingga jika penyimpanan basis data menggunakan OODBMS maka perancangan basis data tidak perlu menggunakan ERD

\section{Kamus Data}

Sukamto dan Salahuddin (2014:73), "Kamus data (data dictionary) adalah kumpulan daftar elemen data yang mengalir pada sistem perangkat lunak sehingga masukan (input) dan keluaran (output) dapat dipahami secara umum (memiliki standar cara penulisan)"

\section{PHP (Hypertext Preprocessor)}

Kadir (2008:2), PHP merupakan singkatan dari Hypertext Preprocessor. Ia merupakan bahasa berbentuk skrip yang ditempatkan dalam server dan diproses diserver. Hasilnyalah yang dikirimkan ke klien. Tempat pemakai menggunakan browser. Secara khusus, PHP dirancang untuk membentuk aplikasi web dinamin. Artinya, ia dapat membentuk suatu tampilan berdasarkan permintaan terkini 


\section{Adobe Dreamweaver}

Sadeli (2013:12) menjelaskan, Dreamweaver merupakan suatu perangkat lunak web editor keluaran Adobe System yang digunakan untuk membangun dan mendesain suatu website dengan fitur-fitur yang menarik dan kemudahan dalam penggunaannya.

\section{XАMMP}

Nugroho (2013:1), XAMPP adalah paket program web lengkap yang dapat anda pakai untuk belajar pemrograman web, khususnya PHP dan MySQL, paket ini dapat didownload secara gratis dan legal.

\section{$S Q L$}

Sukamto dan Shalahuddin (2013:46), "SQL (Structured Query Language) adalah bahasa yang digunakan untuk mengelola data pada $R D B M S^{\prime}$.

\section{METODE PENELITIAN}

Untuk mengumpulkan data serta informasi yang diperlukan, maka penulis akan menggunakan metode sebagai berikut:

a. Penelitian Pustaka (library Research), dilakukan dengan mempelajari referensi, informasi melalui internet dan sumber yang berhubungan dengan penulisan Tugas Akhir.

b. Penelitian Lapangan (Field Research), jenis pengumpulan data dengan melakukan pengamatan langsung dilapangan. Dengan menggunakan teknik sebagai berikut:

1. Teknik Observasi adalah teknik yang dilakukan dengan cara mengadakan pengamatan secara langsung mengenai sistem yang berjalan.
2. Teknik Interview (wawancara) adalah melakukan wawancara dengan Pimpinan atau Staf untuk mendapatkan data yang berhubungan dengan Penelitian.

\section{Alat dan Bahan yang digunakan}

Perangkat Keras yang dibutuhkan adalah

a. Laptop Asus Processor Intel

b. Memory $120 \mathrm{MB}$ HD $60 \mathrm{~GB}$

c. Hardsik $500 \mathrm{~GB}$

d. Printer

Perangkat lunak yang digunakan adalah

a. Sistem Operasi Windows 7 Ultimate

b. Adobe Dreamweaver

c. Bahasa Pemrograman HTML, MySql, PHP

d. Microsoft Word 2007

e. Notepad++

\section{Kerangka Penilitian}

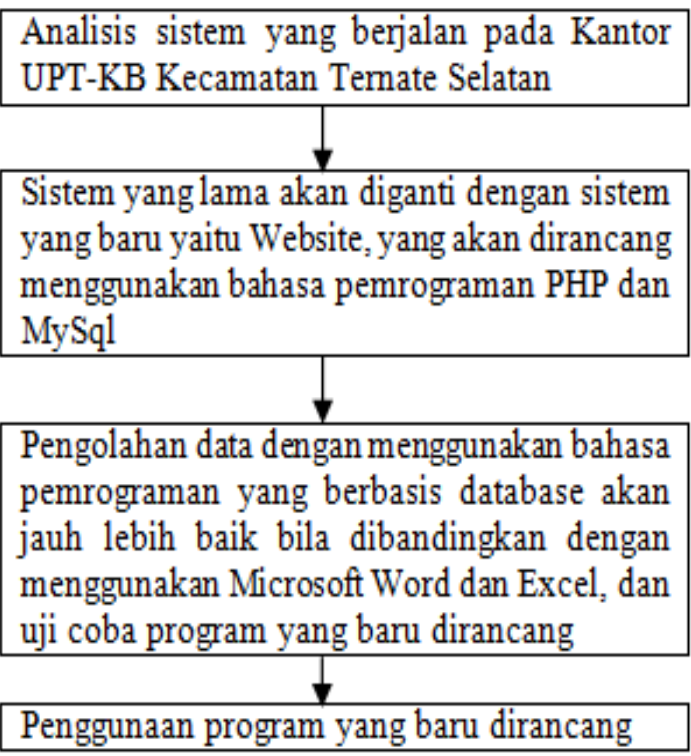

Gambar 1. Kerangka Penilitian

\section{Analisa Sistem yang Berjalan}

Analisis sistem berjalan pada Kantor UPT-KB kec.Ternate Selatan tentang pengolahan data balita masih menggunakan sistem komputerisasi manual, yaitu data diolah dan disajikan 
masih menggunakan aplikasi word dan excel, dan harus diolah lagi oleh BPKKBD kemudian dikembalikan lagi ke UPT-KB kec.Ternate Selatan untuk dianalisa sebelum diberikan ke BKKBN provinsi

\section{Rancangan System yang Diusulkan}

Berdasarkan sistem yang berjalan maka peneliti mengusulkan konsep rancangan sistem yang baru. Sebagai berikut:.

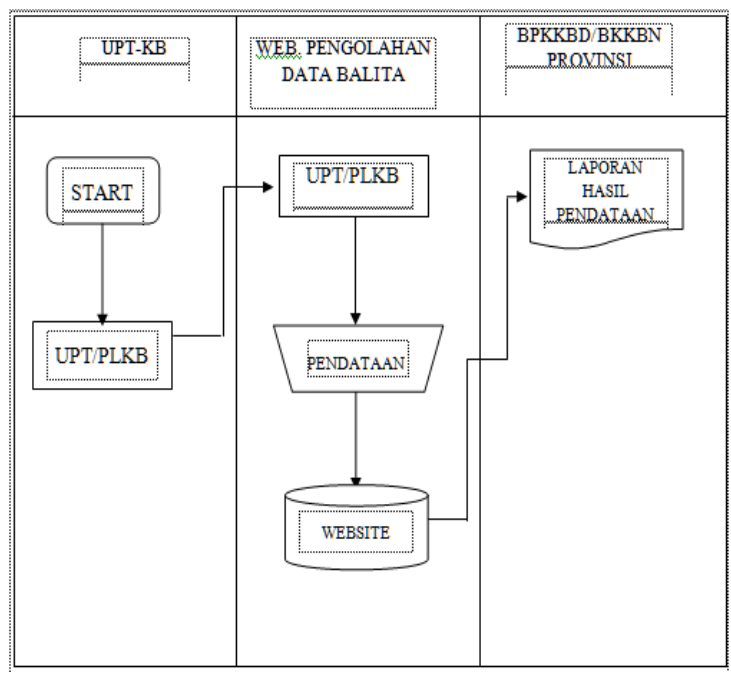

Gambar 2. Flowchart Sistem Yang

Diusulkan

\section{Kebutuhan Fungsional}

Kebutuhan Fungsional Sistem Informasi Pengolahan Data Balita sebagai berikut :

a. Sistem dapat melakukan penginputan Data Balita, Data Ayah dan Data Ibu

b. Sistem harus dapat menampilkan hasil dari penginputan data yang telah berhasil.

\section{Kebutuhan Non-Fungsional}

a. System Dapat dijalankan pada software web browser Google Chrome.

b. Sistem dapat di akses oleh petugas atau admin yang diberikan hak akses.

c. Sistem menggunakan bahasa pemrograman $H T M L, C S S, P H P$

d. Sistem dijalan pada Localhost $X A M P P$

PERANCANGAN SISTEM Perancangan Tabel Database

Tabel 1. Data Balita

\begin{tabular}{|l|l|l|l|l|}
\hline Name & Type & $\begin{array}{c}\text { Widt } \\
\text { h }\end{array}$ & Index & $\begin{array}{l}\text { Keteranga } \\
\text { n }\end{array}$ \\
\hline Id_balita & Int & 20 & $\begin{array}{l}\text { Primar } \\
\text { y Key }\end{array}$ & $\begin{array}{l}\text { No } \\
\text { identitas } \\
\text { balita }\end{array}$ \\
\hline $\begin{array}{l}\text { Nm_bali } \\
\text { ta }\end{array}$ & $\begin{array}{l}\text { Varch } \\
\text { ar }\end{array}$ & 20 & $\begin{array}{l}\text { Nama } \\
\text { balita }\end{array}$ \\
\hline Jk & Enum & & & $\begin{array}{l}\text { Jenis } \\
\text { kelamin } \\
\text { balita }\end{array}$ \\
\hline $\begin{array}{l}\text { Tmp_lah } \\
\text { ir }\end{array}$ & $\begin{array}{l}\text { Varch } \\
\text { ar }\end{array}$ & 20 & $\begin{array}{l}\text { Tempat } \\
\text { Lahir } \\
\text { Balita }\end{array}$ \\
\hline Tgl_lahir & $\begin{array}{l}\text { Varch } \\
\text { ar }\end{array}$ & 20 & $\begin{array}{l}\text { Tanggal } \\
\text { Lahir } \\
\text { Balita }\end{array}$ \\
\hline $\begin{array}{l}\text { NIK_aya } \\
\text { h }\end{array}$ & $\begin{array}{l}\text { Varch } \\
\text { ar }\end{array}$ & 20 & & $\begin{array}{l}\text { NIK Ayah } \\
\text { Balita }\end{array}$ \\
\hline NIK_ibu & $\begin{array}{l}\text { Varch } \\
\text { ar }\end{array}$ & 20 & & $\begin{array}{l}\text { NIK } \\
\text { Balita }\end{array}$ \\
\hline
\end{tabular}

Tabel 2. Data Ayah

\begin{tabular}{|l|l|l|l|l|}
\hline \multicolumn{1}{|c|}{ Name } & Type & $\begin{array}{c}\text { Wid } \\
\text { th }\end{array}$ & Index & $\begin{array}{l}\text { Keteran } \\
\text { gan }\end{array}$ \\
\hline NIK ayah & Bigint & 20 & $\begin{array}{l}\text { Prima } \\
\text { ry } \\
\text { Key }\end{array}$ & NIK ayah \\
\hline Nm_ayah & $\begin{array}{l}\text { Varch } \\
\text { ar }\end{array}$ & 20 & & $\begin{array}{l}\text { Nama } \\
\text { ayah }\end{array}$ \\
\hline $\begin{array}{l}\text { Tmp_lahir_ } \\
\text { ayah }\end{array}$ & $\begin{array}{l}\text { Varch } \\
\text { ar }\end{array}$ & 20 & $\begin{array}{l}\text { Tempat } \\
\text { lahir } \\
\text { ayah }\end{array}$ \\
\hline $\begin{array}{l}\text { Tgl_lahir_ay } \\
\text { ah }\end{array}$ & $\begin{array}{l}\text { Varch } \\
\text { ar }\end{array}$ & 20 & $\begin{array}{l}\text { Tanggal } \\
\text { lahir } \\
\text { ayah }\end{array}$ \\
\hline alamat_ayah & $\begin{array}{l}\text { Text } \\
\text { Pendidikan_ } \\
\text { ayah }\end{array}$ & $\begin{array}{l}\text { Varch } \\
\text { ar }\end{array}$ & 20 & $\begin{array}{l}\text { Alamat } \\
\text { ayah }\end{array}$ \\
\hline $\begin{array}{l}\text { Pekerjaan_a } \\
\text { yah }\end{array}$ & $\begin{array}{l}\text { Varch } \\
\text { ar }\end{array}$ & 20 & $\begin{array}{l}\text { Pendidik } \\
\text { an }\end{array}$ \\
\hline Agama_ayah & $\begin{array}{l}\text { Varch } \\
\text { ar }\end{array}$ & 15 & $\begin{array}{l}\text { Pekerjaa } \\
\text { n Ayah }\end{array}$ \\
\hline
\end{tabular}


Tabel 3. Data Ibu

\begin{tabular}{|c|c|c|c|c|}
\hline Name & Type & $\begin{array}{c}\text { Widt } \\
\text { h }\end{array}$ & Index & $\begin{array}{c}\text { Keterang } \\
\text { an }\end{array}$ \\
\hline NIK_ibu & Bigint & 20 & $\begin{array}{l}\text { Prima } \\
\text { ry } \\
\text { Key }\end{array}$ & NIK ayah \\
\hline $\mathrm{Nm} \_\mathrm{ibu}$ & $\begin{array}{l}\text { Varch } \\
\text { ar }\end{array}$ & 20 & & $\begin{array}{l}\text { Nama } \\
\text { ayah }\end{array}$ \\
\hline $\begin{array}{l}\text { Tmp_lahir } \\
\text { _ ibu }\end{array}$ & $\begin{array}{l}\text { Varch } \\
\text { ar }\end{array}$ & 20 & & $\begin{array}{l}\text { Tempat } \\
\text { lahir ayah }\end{array}$ \\
\hline $\begin{array}{l}\text { Tgl_lahir_i } \\
\text { bu }\end{array}$ & $\begin{array}{l}\text { Varch } \\
\text { ar }\end{array}$ & 20 & & $\begin{array}{l}\text { Tanggal } \\
\text { lahir ayah }\end{array}$ \\
\hline alamat_ibu & Text & 20 & & $\begin{array}{l}\text { Alamat } \\
\text { ayah }\end{array}$ \\
\hline Pendidikan & $\begin{array}{l}\text { Varch } \\
\text { ar }\end{array}$ & 20 & & $\begin{array}{l}\text { Pendidika } \\
\mathrm{n}\end{array}$ \\
\hline Pekerjaan & $\begin{array}{l}\text { Varch } \\
\text { ar }\end{array}$ & 20 & & $\begin{array}{l}\text { Pekerjaan } \\
\text { Ayah }\end{array}$ \\
\hline $\begin{array}{l}\text { Agama_ib } \\
\mathrm{u}\end{array}$ & $\begin{array}{l}\text { Varch } \\
\text { ar }\end{array}$ & 15 & & $\begin{array}{l}\text { Pekerjaan } \\
\text { Ayah }\end{array}$ \\
\hline
\end{tabular}

\section{Diagram Konteks}

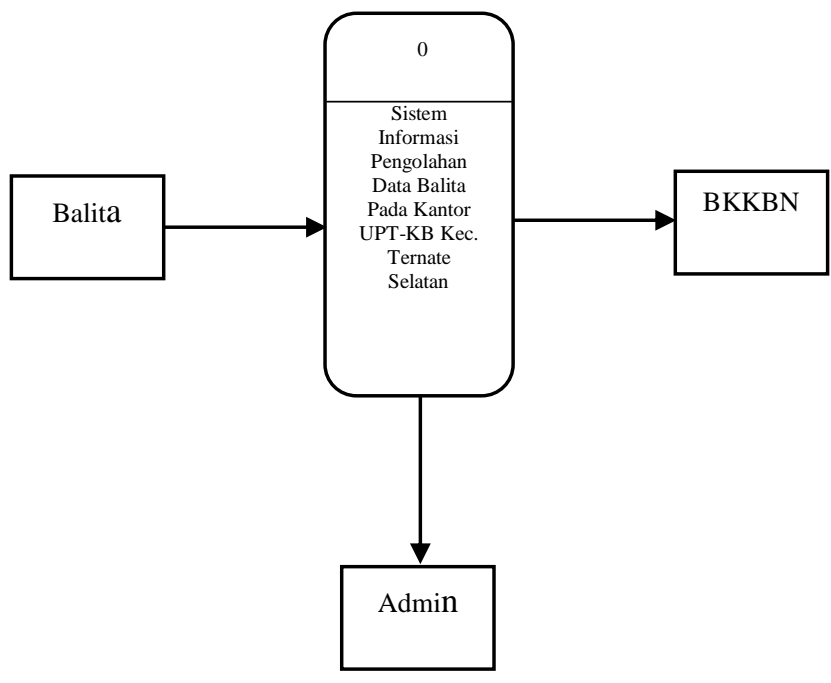

Gambar 3. Diagram Konteks

\section{DFD Level 0}

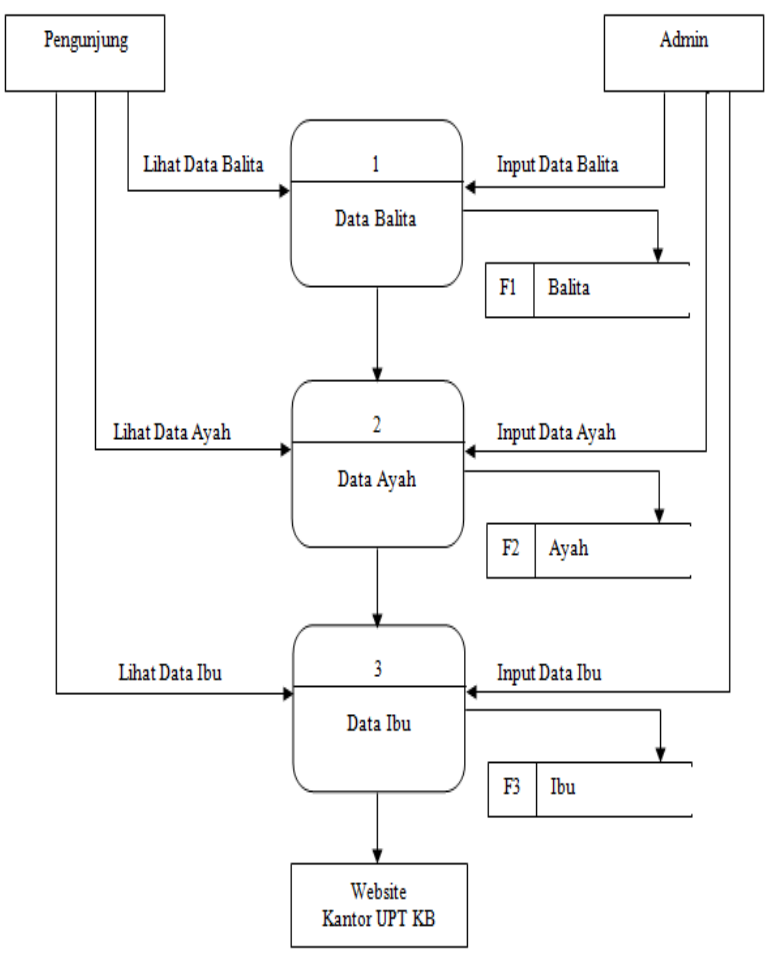

Gambar 4. Diagram Level 0

\section{ERD Relasi Tabel}

Entity Relationship Diagram atau yang biasa disingkat ERD merupakan rancangan model database relasi antar entity dan objek, berikut merupakan hasil rancagan ERD relasi tabel

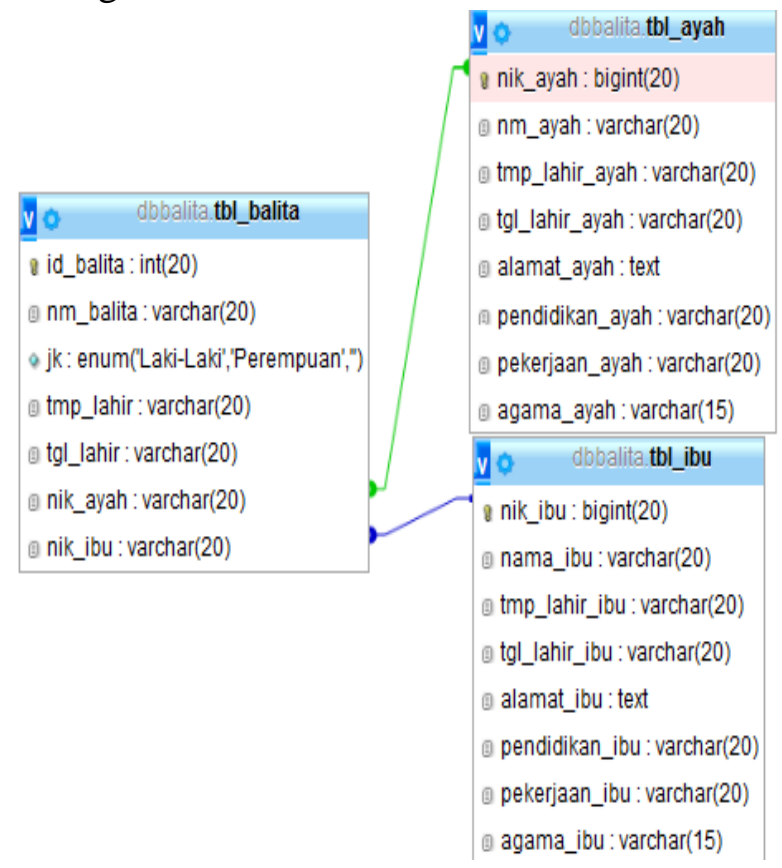

Gambar 5. Relasi Tabel 


\section{IMPLEMENTASI SISTEM}

Implementasi yang merupakan terjemahan dari kata "implementation" berasal dari kata kerja "to implement" yang artinya untuk melaksanakan. Secara sederhana implementasi bisa diartikan pelaksanaan atau penerapan. Sehubungan dengan kata implementasi ini, Pressman dan Aaron Wildavsky mengemukakan bahwa "implementation as to carry out, accomplish fulfill, produce, complete" maksudnya implementasi yaitu untuk membawa, menyelesaikan, mengisi, menghasilkan dan melengkapi. Jadi secara etimologis implementasi itu dapat dimaksudkan sebagai suatu aktivitas yang bertalian dengan penyelesaian suatu pekerjaan dengan penggunaan sarana (alat) untuk memperoleh hasil. Purwanto \& Sulistyastuti (2012),

\section{Menu Utama}

Menu utama merupakan awal tampilan saat masuk dalam website sistem pengolahan data balita kantor UPT-KB Kec. Ternate Selatan, berikut tampilan gambar menu utama:

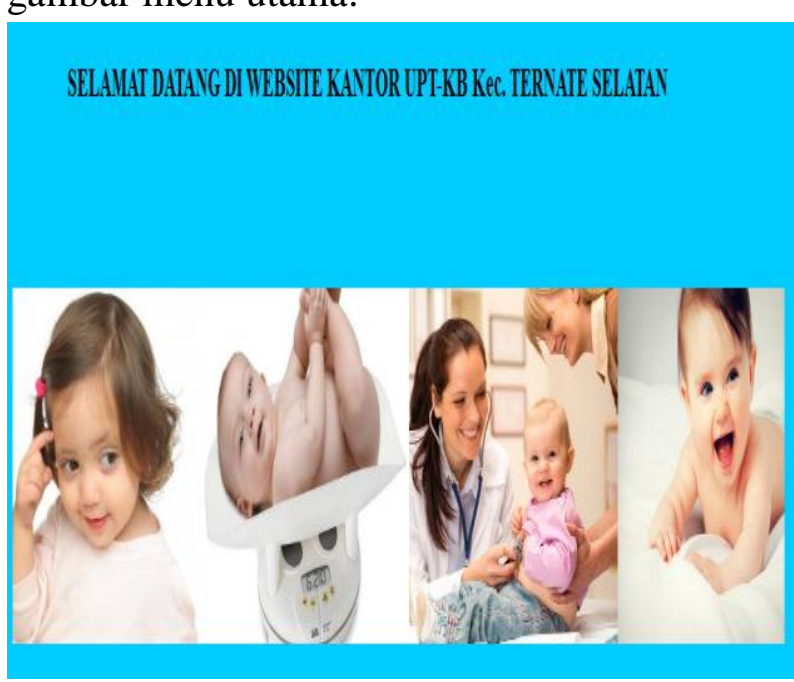

Gambar 6. Tampilan Menu utama

\section{Halaman Menu Login}

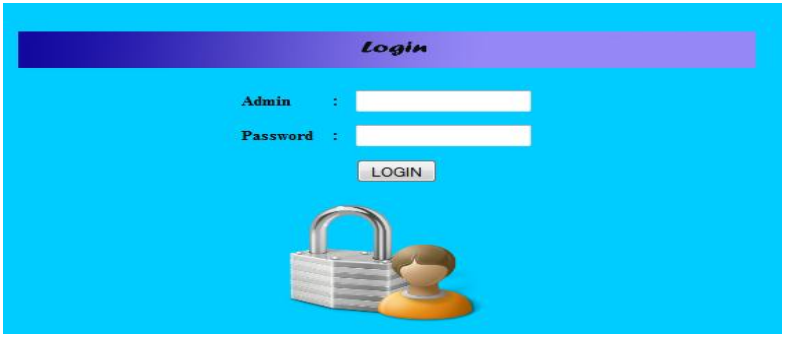

Gambar 7. Menu Login Admin

\section{Halaman Input Data Balita}

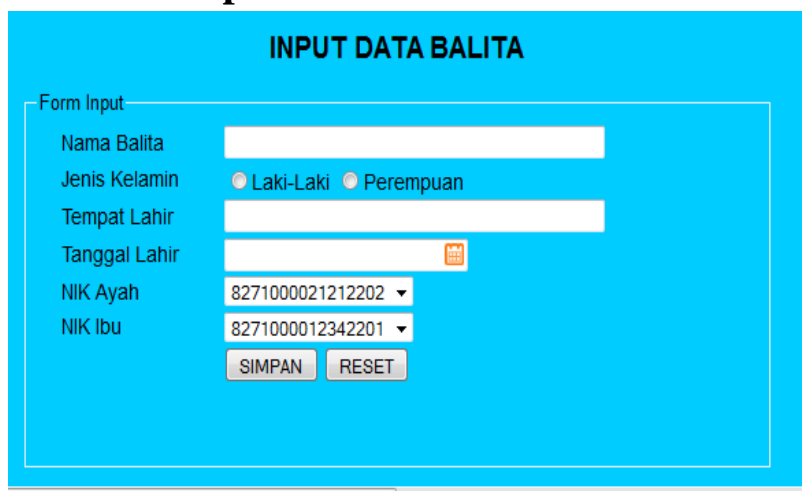

Gambar 8. Menu Input Data Balita

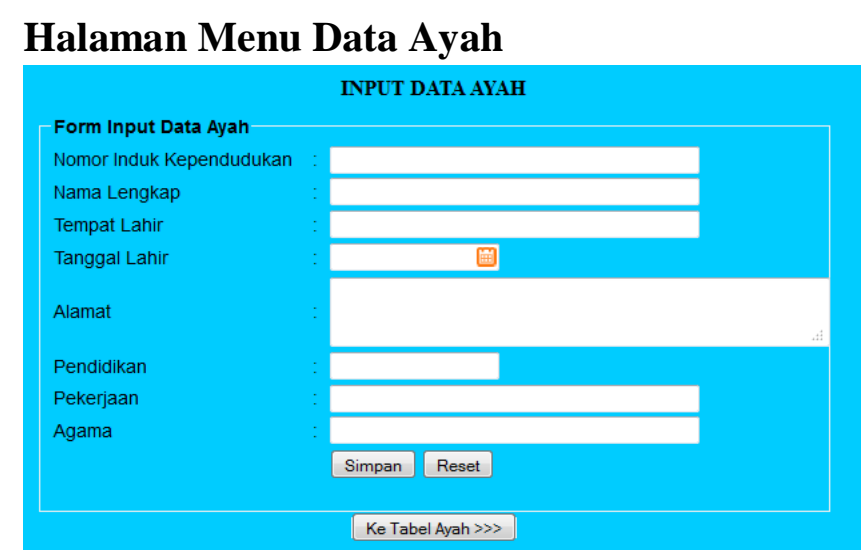

Gambar 9. Menu Data Ayah

\section{Halaman Menu Data Ibu}

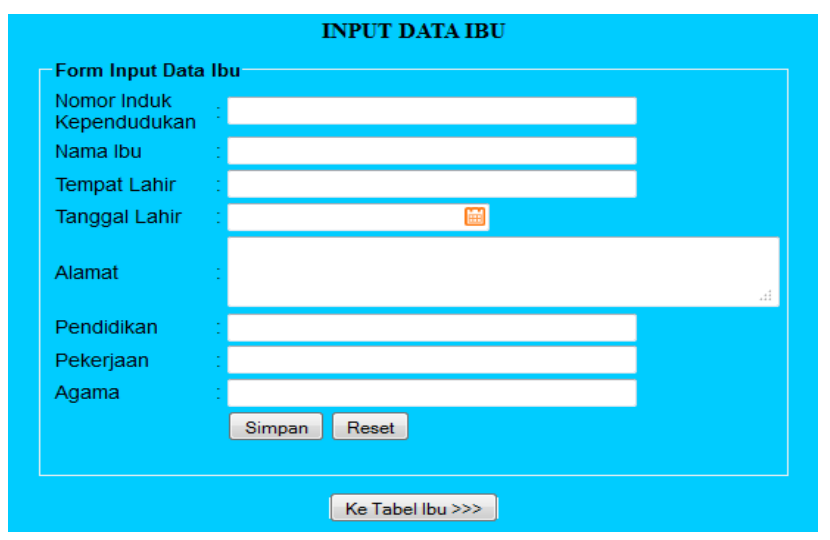

Gambar 10. Menu Data Ibu 


\section{KESIMPULAN}

Berdasarkan hasil implementasi Sistem Informasi Pengolahan Data balita berbasis web pada Kantor UPT-KB Kec. Ternate Selatan dapat di berikan kesimpulan sebagai berikut: 1). mempermudah pegawai UPT-KB dalam mengolah data balita pada Kantor UPTKB kec. Ternate. 2). Dapat menunjang pelayanan para pegawai Kantor UPT-KB kec. Ternate Selatan khususnya dalam Pengolahan Data Balita.

Berdasarkan kesimpulan dapat disarankan untuk pengembangan selanjutnya sebagai berikut: 1). Pada Sistem perlu ditambahkan hasil secara grafik dari jumlah balita disetiap kelurahan per tahunnya. 2). Tampilan user interface menu di perlu diberikan informasi interaksi agar pengguna sistem dapat memahami kesalahan-kesalahan yang terjadi pada sistem nantinya

\section{DAFTAR PUSTAKA}

Sutabri, Tata. S.Kom, MM. (2004). Analisa Sistem Informasi. Edisi Pertama. Yogyakarta: Andi

Abdul Kadir. 2008. Dasar Pemrograman

Web Dinamis Menggunakan PHP. Andi: Yogyakarta

Agus Mulyanto. 2009. Sistem Informasi

Konsep dan Aplikasi. Pustaka Pelajar. Yogyakarta

eWolf, Community. 2011. Indeks Lengkap

Syntax. MediaKom: Yogyakarta.

Purwanto \& Sulistyastuti, 2012, Implementasi Kebijakan Publik

Konsep dan Aplikasinya di Indonesia, GAVA MEDIA: Yogyakarta

Sutarman. 2012. Pengantar Teknologi Informasi. Bumi Aksara: Jakarta
Tata Sutabri. 2012. Analisis Sistem Informasi. Andi. Yogyakarta

Yakub. 2012. Pengantar Sistem Informasi. Graha Ilmu: Yogyakarta.

Azhar Susanto. 2013. Sistem Informasi Akuntansi Edisi Sembilan. Andi: Yogyakarta.

Nugroho, Bunafit. 2013. Dasar Pemograman Web PHP - MySQL dengan Dreamweaver. Gava Media: Yogyakarta

Sadeli, Muhammad. 2013. Dreamweaver CS6 Untuk Orang Awam. Maxikom: Palembang

Sukamto dan Shalahuddin. 2013. Rekayasa Perangkat Lunak Terstruktur dan Berorientasi Objek. Informatika Bandung: Bandung.

Hutahaean, Jeperson. 2014. Konsep Sistem Informasi. Yogyakarta: Deepublish

Sukamto, R. A., dan Shalahudin, M. 2014, Rekayasa Perangkat Lunak

Profil kantor UPT-KB Kecamatan Ternate Selatan, 2015

Mulyadi, 2016, Sistem Akuntansi. Salemba Empat: Jakarta

Muhdar Abdurahman, Sistem Informasi Data Pegawai Berbasis Web Pada Kementerian Kelautan Dan Perikanan Kota Ternate, Jurnal Ilmiah ILKOMINFO - Jurnal Ilmu Komputer dan Informatika, Volume 1 No 2 Juli 2018, eISSN: 2621-4970, pISSN: 2621-4962 